\title{
Absorption and Translocation of Glyphosate by Carrot Infected by Swamp Dodder
}

Thomas A. Bewick

Vegetable Crops Department, University of Florida, Gainesville, FL 32611

Larry K. Binning

Horticulture Department, University of Wisconsin, Madison, WI 53706

Nelson E. Balke

Agronomy Department, University of Wisconsin, Madison, WI 53706

Additional index words. Cuscuta gronovii, Daucus carota, physiological sink, phloem-mobile herbicide

\begin{abstract}
Absorption of "C-labeled glyphosate by whole carrot (Daucus carota L.) plants infected or not infected by swamp dodder (Cuscuta gronovii Willd ex R \& S) increased from $14 \% 1$ day after treatment to $56 \% 14$ days after treatment. Absorption of ${ }^{14} \mathrm{C}$-labeled glyphosate did not increase from 14 to 45 days after treatment. ${ }^{14}$ Carbon-labeled glyphosate appeared in the carrot root 1 day after application and its concentration increased with time in both infected and noninfected plants until 14 days after treatment. From 14 to 45 days after treatment, the concentration of ${ }^{14} \mathrm{C}$-labeled glyphosate in the roots decreased. At 1 day after treatment, dodder tissue contained as much ${ }^{14} \mathrm{C}$ labeled glyphosate as any physiological sink in the carrot. At 45 days after treatment, dodder tissue contained more ${ }^{14} \mathrm{C}$-labeled glyphosate than all other physiological sinks, except the petiole of the treated leaf. Swamp dodder stems had absorbed ${ }^{14} \mathrm{C}$-labeled glyphosate directly from a solution within 1 day after treatment. Chemical name used: $\mathrm{N}$ (phosphonomethyl)glycine (glyphosphate).
\end{abstract}

Dodder (Cuscuta spp.) is a problem weed in various horticultural crops (Dawson et al., 1984), including carrot. Dodder is a phanerogamic parasite that invades host plants by means of haustoria. The haustoria grow between the host cells and produce "hyphae" of two types. Search hyphae grow either interor intra-cellularly until contacting host sieve tube elements. The tip of the hyphae differentiates several finger-like projections, the contact hyphae. These grow between the sieve tube element and the surrounding host cells (Kuijt, 1977). It is through the haustoria that dodder obtains photoassimilates from the host plant. There is evidence that dodder obtains the majority of its growth substances from the host phloem (Wolswinkel, 1977). Phloem-mobile herbicides, such as glyphosate (GLY), are more efficient in entering dodder tissue from the host than are xylemmobile herbicides (Fer, 1981).

GLY is a broad-spectrum herbicide with value as a postemergence control agent for various weed species (Baird et al., 1971). GLY moves in the symplast in a source-to-sink fashion (McAllister and Haderlie, 1985). Putnam (1976) found 92\% to 98\% of applied GLY as the parent compound 90 days after application to deciduous fruit trees, indicating that plant metabolism of GLY is negligible. Control of dodder growing parasitically on crop plants maybe possible with broadcast applications of GLY (Bewick et al., 1988a; Dawson and Saghir, 1983). In cranberry, GLY applied to leaves above the berry was not translocated into the berry (Bewick et al., 1988b), indicating that it may be safe to apply GLY directly to crops for human consumption. Carrot can tolerate as much as $0.8 \mathrm{~kg}$ GLY/ha without reduction in root yield, depending on environmental conditions (R. Jacobsohn, personal communication, Vegetable Crops Dept., Volcani Inst., Bet Dagan, Israel). In field research, two applications of $0.6 \mathrm{~kg} \cdot \mathrm{ha}^{-1}$ spaced 1 week apart did not reduce carrot yield, while dodder infestation was controlled (Bewick et al., 1988a).

Received for publication 12 Dec. 1990. Florida Agr. Expt. Sta. Bul. no. R01213. The cost of publishing this paper was defrayed in part by the payment of page charges. Under postal regulations, this paper therefore must be hereby marked advertisement solely to indicate this fact.
We determined whether the physiological sink created by dodder in the host plant prevented accumulation of GLY in the edible portion of carrot and whether swamp dodder stems were able to absorb GLY.

\section{Materials and Methods}

Short-term absorption and translocation of ${ }^{14} \mathrm{C}$-labeled $G L Y$ in carrot. Carrot plants were grown in a computer-monitored controlled environment. 'Danvers 126' carrots were seeded into a commercial soil mix in 15 -cm-diameter plastic pots $(2650$ $\mathrm{cm}^{3}$ ) and thinned to one plant per pot. The environmental conditions during growth were: radiation, $760 \mu \mathrm{mol} \cdot \mathrm{m}^{-2} \cdot \mathrm{s}^{-1} ; 16-$ $\mathrm{h}$ photoperiod, lights on and off gradually $(0.5 \mathrm{~h}$ at $20 \%, 0.5$ $\mathrm{h}$ at $50 \%$, then $100 \%$ ); relative humidity, $70 \%$ day and night; automatic watering, 3.5 min every $6 \mathrm{~h}$ with half-strength Hoagland's solution (Hoagland and Arnon, 1950); temperature, 25C day/20C night. The experiment was arranged as a randomized complete block with four replications. Each replication was a single pot. The experiment was repeated.

When the carrot had four leaves, newly emerged dodder seedlings were placed in contact with the third oldest leaf $1 \mathrm{~cm}$ above the soil surface. The dodder seedlings were grown by planting scarified swamp dodder seeds in foam plugs (Castle and Cooke Techniculture, Salinas, Calif.) and placing them in a dark growth chamber at 30C. The host-parasite system was allowed to grow for 2 weeks after parasitism occurred.

${ }^{14}$ Carbon-labeled methyl GLY $(0.25 \mu \mathrm{Ci} ; 1 \mathrm{Ci}=37 \mathrm{GBq})$ was applied to the parasitized leaf. The labeled herbicide had a specific activity of $1.97 \mu \mathrm{Ci} / \mu \mathrm{mol}$ and was mixed with distilled water to a concentration of $2.02 \mu \mathrm{Ci} / \mathrm{ml} .{ }^{14} \mathrm{Carbon}-l a b e l e d$ GLY was mixed with the commercial herbicide formulation so that $2.57 \mu \mathrm{mol}$ of total GLY was applied to each plant (Coupland and Peabody, 1981; Davis et al., 1979). Less than $0.001 \mu \mathrm{mol}$ was applied as the free acid. Distilled water was added to the mixture so that $0.5 \mathrm{ml}$ of solution was applied to each plant with a micropipette. Carrot plants not infected by dodder were

Abbreviations: DAT, days after treatment; GLY, glyphosate. 
treated with the GLY mixture at the same time and in the same manner.

Carrot plants, four each for infected and control plants, were harvested 1, 7, and 14 days after treatment (DAT). At harvest, the treated leaves were washed with two 10-ml aliquots of a solution containing $10.0 \%$ ethanol, $89.9 \%$ distilled water, and $0.1 \%$ polysorbate [polyoxyethylene (20) sorbitan monolaurate] to remove any GLY that remained on the leaf surface (Devine et al., 1984; Waldecker and Wyse, 1985). Dodder stems were rinsed with the same solution. The carrot plants were divided into parts that represented physiological sinks: treated leaf, petiole of treated leaf, crown, youngest leaf at application, new leaves formed after application, top third of taproot, middle third of taproot, and bottom third of taproot.

Tissue was weighed, lyophilized, and reweighed. The lyophilized tissue was ground in a Wiley mill and, when necessary, 50-mg subsamples were taken. The samples (or subsamples) were oxidized in a biological oxidizer (Harvey Instrument Co., Hillsdale, N.J.), which trapped the ${ }^{14} \mathrm{CO}_{2}$ in a scintillation cocktail. The amount of ${ }^{14} \mathrm{C}$-labeled GLY present in the tissue was determined by scintillation spectrometry (Rackbeta, LKB Instruments, Gaithersburg, Md.). Background radiation was determined by combusting 50-mg samples of mannitol, trapping the $\mathrm{CO}_{2}$ in the same cocktail as the samples, and using scintillation spectrometry. The mean value for background radiation was subtracted from the values for the samples before statistical analysis. Oxidizer efficiency was determined by adding 10,000 $\mathrm{dpm}$ of ${ }^{14} \mathrm{C}$-labeled glutamic acid to $50-\mathrm{mg}$ samples of mannitol, combusting it in the oxidizer, and using' scintillation spectrometry. Sample values were divided by the mean value of oxidizer efficiency before statistical analysis of the data.

Long-term absorption and translocation of ${ }^{14}$ C-labeled GLY in carrot. 'Danvers 126' carrots were seeded into a commercial soil mix in 23 -cm-diameter plastic pots $\left(10,500 \mathrm{~cm}^{3}\right)$ and thinned to one plant per pot. The plants were grown in a greenhouse at 15 to $30 \mathrm{C}$ under natural daylight and photoperiod. An automatic watering system ran four times per day for a total of $12 \mathrm{~min}$. Drip tubes (three per plant) were used to prevent rinsing GLY from the foliage. The plants were. infected with dodder and treated with ${ }^{14} \mathrm{C}$-labeled methyl GLY as before. The plants were allowed to grow 45 DAT before harvest. Carrots harvested at this time were 108 days old, which corresponds to the length of time commercial processing carrots are grown in the field. The experiment was arranged as a randomized complete block with four replications. Each replication was a single pot. The experiment was repeated.

Plants were harvested with the same procedure as before. The lyophilized tissue was subsampled $(50 \mathrm{mg})$ by grinding in a mortar and pestle under liquid nitrogen. Samples (or subsamples) were oxidized (Model 306 Packard oxidizer; Packard Instrument Co., Downers Grove, 111.) and the amount of label present determined by scintillation spectrometry (Beckman LS7500; Beckman Instruments, Irvine, Calif.). Background radiation was determined by combusting 50-mg samples of untreated carrot root tissue; oxidizer efficiency was determined by applying $30,000 \mathrm{dpm}$ of ${ }^{14} \mathrm{C}$-labeled hexadecane to $50 \mathrm{-mg}$ samples of mannitol, combusting, and using scintillation spectrometry. Sample values were modified, as noted, before statistical analysis.

Absorption of ${ }^{14} C$-labeled GLY directly by dodder. This experiment was done to determine whether the presence of swamp dodder in the field could have prevented the GLY spray from reaching the carrot foliage while causing phytotoxic effects in the dodder. Carrot and dodder were grown as previously described. The dodder stem was forced to grow into an inverted 25-ml scintillation vial. After filling with dodder tissue, the vial was righted and the dodder was treated with $0.25 \mu \mathrm{Ci}$ of ${ }^{14} \mathrm{C}$ labeled GLY mixed with the commercial formulation as before. Distilled water was added to the vial to cover the dodder tissue. The dodder tissue was harvested 1 DAT.

General and statistical procedures. Analysis of variance revealed there were no interactions between experiments; thus, the data were combined across experiments. Data for ${ }^{14} \mathrm{C}$ content were square-root transformed to ensure equal variance among the samples. Data were analyzed with a two-way analysis of variance of the square root of the disintegrations per minute per milligram of dry weight and means were compared with a protected LSD at $P=0.05$.

Percent GLY absorption was determined by multiplying the total weight of the various tissues at each sample date by the disintegrations per minute per milligram of dry weight for that tissue, adding all values together to determine the total disintegrations per minute on a whole-plant basis, dividing the sum by the total disintegrations per minute applied, and multiplying by 100 . Total disintegrations per minute applied was calculated by multiplying microCuries applied by $2.2 \times 10^{6} \mathrm{dpm} / \mu \mathrm{Ci}$. Analysis of variance was used to determine whether absorption increased with time, and means were separated with a protected LSD at $P=0.0 .5$.

A concentration in parts per million, based on dry weight, was calculated for the carrot tissue at each sample date. The total dry weight of the various tissues was multiplied by the disintegrations per minute per milligram of dry weight. The product was converted into a percentage of the total disintegrations per minute applied, as previously described. The total amount of GLY applied per plant was multiplied by the percentage of ${ }^{14} \mathrm{C}$-labeled GLY that had been translocated to the tissue to determine the number of micromoles of GLY in the tissue. This product was multiplied by the molecular weight of GLY $\left(169.1 \mathrm{~g} \cdot \mathrm{mol}^{-1}\right)$ to yield the weight of GLY in the tissue. The concentration was determined by dividing the weight of GLY in the tissue by the total tissue weight. The concentration of GLY in the entire root was determined by adding the total $\mathrm{dpm}$ for the three root sections to yield total dpm for the whole root. This sum was converted to a concentration as described above. Two-way analysis of variance was used to determine whether the concentration of GLY in the various tissues or the whole root increased with time. Means were separated as before.

Two-way analysis of variance using indicator variables (Snedecor and Cochran, 1982) was used to determine whether dodder infection protected the carrot plants from the herbicidal effects of GLY. The indicator variables were plant part sampled and whether or not a plant was infected with dodder.

\section{Results and Discussion}

Absorption and translocation of ${ }^{14}$ C-labeled GLY in carrot. On a whole-plant basis, absorption of ${ }^{14} \mathrm{C}$-labeled GLY was not increased by dodder infection, as determined by the indicator variable analysis. GLY absorption in the whole plant increased from 14\% 1 DAT to 27\% 7 DAT and 56\% 14 DAT. Absorption did not increase from 14 to 45 DAT $(55 \%)$.

Day 1 after treatment. ${ }^{14}$ Carbon-labeled GLY could be detected in all carrot root tissue 1 DAT (Table 1) The treated leaf of plants infected or. not infected by dodder contained more ${ }^{14} \mathrm{C}$ labeled GLY than the other tissues sampled. The petiole from 
Table 1. Distribution of GLY in carrot in relation to infection by swamp dodder and time after treatment. $^{2}$

\begin{tabular}{|c|c|c|c|c|c|c|c|c|}
\hline \multirow[b]{3}{*}{ Physiological sink } & \multicolumn{4}{|c|}{ Infected } & \multicolumn{4}{|c|}{ Not infected } \\
\hline & \multicolumn{8}{|c|}{ DAT } \\
\hline & 1 & 7 & 14 & 45 & 1 & 7 & 14 & 45 \\
\hline & \multicolumn{8}{|c|}{$d p m / m g$} \\
\hline Treated leaf & $100 \mathrm{a}$ & $144 \mathrm{a}$ & $144 \mathrm{a}$ & $198 \mathrm{a}$ & $33.1 \mathrm{a}$ & 67 & $52 \mathrm{a}$ & $255 \mathrm{a}$ \\
\hline Petiole of treated leaf & $9 \mathrm{~b}$ & $46 \mathrm{~b}$ & 22 cde & $53 \mathrm{~b}$ & $1.7 \mathrm{~b}$ & $40 \mathrm{~b}$ & 15 bcd & $41 \mathrm{~b}$ \\
\hline Dodder & $2 c$ & $58 \mathrm{~b}$ & $47 \mathrm{~b}$ & $43 \mathrm{~b}$ & --- & --- & --- & -- \\
\hline Crown & $2 c$ & $16 \mathrm{ef}$ & 12 ef & $11 \mathrm{c}$ & $1.2 \mathrm{bc}$ & $8 \mathrm{c}$ & $9 \mathrm{~cd}$ & $5 c$ \\
\hline \multicolumn{9}{|l|}{ Root } \\
\hline Top third & $1 \mathrm{c}$ & $20 \mathrm{de}$ & $16 \mathrm{def}$ & $8 \mathrm{c}$ & $0.4 \mathrm{c}$ & $7 \mathrm{c}$ & $29 a b$ & $5 \mathrm{c}$ \\
\hline Middle third & $1 \mathrm{c}$ & 11 ef & $40 \mathrm{bc}$ & $8 \mathrm{c}$ & $0.4 \mathrm{c}$ & $7 \mathrm{c}$ & $23 \mathrm{bc}$ & $4 \mathrm{c}$ \\
\hline Bottom third & $2 c$ & $9 \mathrm{f}$ & 9 ef & $6 \mathrm{c}$ & $0.9 \mathrm{bc}$ & $6 \mathrm{c}$ & $9 \mathrm{~cd}$ & $5 \mathrm{c}$ \\
\hline \multicolumn{9}{|l|}{$\begin{array}{l}\text { Youngest leaf at time of } \\
\text { GLY application }\end{array}$} \\
\hline $\begin{array}{l}\text { GLY application } \\
\text { New leaves formed after }\end{array}$ & $3 c$ & $32 \mathrm{~cd}$ & $6 \mathrm{f}$ & -- & $1.5 \mathrm{~b}$ & $23 \mathrm{~b}$ & $4 \mathrm{~d}$ & --- \\
\hline GLY application & -- & $39 \mathrm{c}$ & $36 \mathrm{bcd}$ & $5 \mathrm{c}$ & -- & $23 \mathrm{~b}$ & $48 \mathrm{a}$ & $4 c$ \\
\hline
\end{tabular}

${ }^{2}$ Averages of two experiments. Analysis was performed on the square root of disintegrations per minute permilligram of dry weight. Mean separation in columns by LSD, $P=0.05$.

the treated leaf of the dodder-infected plant contained less ${ }^{14} \mathrm{C}$ labeled GLY than the treated leaf but more than the other tissues. All other tissues, including the dodder, had about the same level of ${ }^{14} \mathrm{C}$-labeled GLY (Table 1). In plants not infected with dodder, the youngest leaf at application and the petiole of the treated leaf contained more ${ }^{14} \mathrm{C}$-labeled GLY than did the top or middle third of the carrot root (Table 1). At 1 DAT, the root of the dodder-infected carrot and the root of the carrot not infected with dodder contained similar concentrations of GLY (1.0 vs. 0.4). The GLY concentration in the various tissues sampled (Table 1) followed the same pattern as that obtained for ${ }^{14} \mathrm{C}$-labeled GLY content (Table 2).

Day 7 after treatment. At seven DAT, the treated leaves of plants either infected or not infected by dodder contained more ${ }^{14} \mathrm{C}$-labeled GLY than any of the other tissues sampled. The dodder tissue contained as much ${ }^{14} \mathrm{C}$-labeled GLY as the petiole of the treated leaf and more than any other sink in the plant (Table 1). In both the dodder-infected and noninfected plants, the leaves formed after application contained more ${ }^{14} \mathrm{C}$-labeled
GLY than any parts of the carrot root (Table 1). There also was more ${ }^{14} \mathrm{C}$-labeled GLY in the young, rapidly expanding leaves than in the roots of plants that were not infected with dodder (Table 1). This result indicates that early in the growth of carrot plants, newly forming leaves are stronger physiological sinks than the roots. Again, the root of plants either infected or not infected by dodder contained similar concentrations of ${ }^{14} \mathrm{C}$-labeled GLY (13 vs. 6 ppm). The GLY concentration in the various tissue samples followed the same pattern as that obtained for ${ }^{14} \mathrm{C}$-labeled GLY content (Table 2).

Day 14 after treatment. At 14 DAT, the treated leaf of dodder-infected plants contained more ${ }^{14} \mathrm{C}$-labeled GLY than any other tissue sampled. The dodder tissue contained as much ${ }^{14} \mathrm{C}$ labeled GLY as the leaves formed after application and more than the petiole of the treated leaf (Table 1), indicating that the dodder tissue was acting as a strong physiological sink. The root as a whole had accumulated more ${ }^{14} \mathrm{C}$-labeled GLY than the other tissue sampled (Table 1). In plants not infected by dodder, the leaves formed after application contained as much

Table 2. Concentration of GLY in physiological sinks in carrot plants infected or not infected with dodder.'

\begin{tabular}{|c|c|c|c|c|c|c|c|c|}
\hline \multirow[b]{3}{*}{ Physiological sink } & \multicolumn{4}{|c|}{ Infected } & \multicolumn{4}{|c|}{ Not infected } \\
\hline & \multicolumn{8}{|c|}{ DAT } \\
\hline & 1 & 7 & 14 & 45 & 1 & 7 & 14 & 45 \\
\hline & \multicolumn{8}{|c|}{$p p m$} \\
\hline Treated leaf & $80 \mathrm{~B}$ & $121 \mathrm{~A}$ & $107 \mathrm{~A}$ & $15 \mathrm{DE}$ & $26 \mathrm{DE}$ & $54 \mathrm{BC}$ & $42 \mathrm{CD}$ & $12 \mathrm{E}$ \\
\hline Petiole of treated leaf & $7 \mathrm{BC}$ & $37 \mathrm{~A}$ & $18 \mathrm{~B}$ & $5 \mathrm{BC}$ & $1 \mathrm{C}$ & $14 \mathrm{BC}$ & $11 \mathrm{BC}$ & $5 \mathrm{C}$ \\
\hline Crown & $1 \mathrm{D}$ & $12 \mathrm{~A}$ & $9 \mathrm{~B}$ & $2 \mathrm{D}$ & $1 \mathrm{D}$ & $6 C$ & $6 \mathrm{C}$ & $1 \mathrm{D}$ \\
\hline \multicolumn{9}{|l|}{ Root } \\
\hline Top third & $1 \mathrm{C}$ & $16 \mathrm{~B}$ & $12 \mathrm{~B}$ & $2 \mathrm{C}$ & $1 \mathrm{C}$ & $6 \mathrm{C}$ & $23 \mathrm{~A}$ & $2 \mathrm{C}$ \\
\hline Middle third & $1 \mathrm{~B}$ & $9 \mathrm{~B}$ & $32 \mathrm{~A}$ & $2 \mathrm{~B}$ & $0 \mathrm{~B}$ & $6 \mathrm{~B}$ & $21 \mathrm{~A}$ & $2 \mathrm{~B}$ \\
\hline Bottom third & $1 \mathrm{C}$ & $8 \mathrm{~A}$ & $7 \mathrm{~A}$ & $2 \mathrm{BC}$ & $0 \mathrm{C}$ & $5 \mathrm{AB}$ & $7 \mathrm{~A}$ & $2 \mathrm{C}$ \\
\hline \multicolumn{9}{|l|}{ Youngest leaf at time of } \\
\hline GLY application & $2 \mathrm{~B}$ & $28 \mathrm{~A}$ & $5 \mathrm{~B}$ & -- & $1 \mathrm{~B}$ & $20 \mathrm{~A}$ & $3 \mathrm{~B}$ & --- \\
\hline New leaves formed after & & & & & & & & \\
\hline GLY application & & $33 \mathrm{~A}$ & $29 \mathrm{~A}$ & $3 \mathrm{~B}$ & --- & $20 \mathrm{AB}$ & $35 \mathrm{~A}$ & $3 \mathrm{~B}$ \\
\hline $\operatorname{LSD}(0.05)$ & 13 & 23 & 20 & 3 & 5 & 21 & 18 & 1 \\
\hline
\end{tabular}

${ }^{2}$ Concentration was calculated in parts per million on a dry-weight basis. Mean separation in rows by LSD at $P=0.05$. Mean separation within columns by LSD values given at the bottom of the column. 
Table 3. Weight of the entire root of carrot plants either infected or not infected with dodder and the calculated concentration (dry-weight basis) of GLY in those roots. ${ }^{2}$

\begin{tabular}{lccccc}
\hline \hline & \multicolumn{2}{c}{ Infected } & & \multicolumn{2}{c}{ Not infected } \\
\cline { 2 - 3 } \cline { 5 - 6 } & $\begin{array}{c}\mathrm{Wt} \\
(\mathrm{mg})\end{array}$ & $\begin{array}{c}\text { Concn }^{y} \\
(\mathrm{ppm})\end{array}$ & & $\begin{array}{c}\mathrm{Wt} \\
(\mathrm{mg})\end{array}$ & $\begin{array}{c}\text { Concn }^{y} \\
(\mathrm{ppm})\end{array}$ \\
\hline 1 & 5,080 & 0.96 & & 4,420 & 0.38 \\
7 & 5,030 & 12.82 & & 5,100 & 5.88 \\
14 & 9,750 & 19.58 & 8,080 & 19.62 \\
45 & 17,150 & 2.22 & & 18,800 & 1.67 \\
LSD $(0.05)$ & 6,676 & 7.05 & 3,434 & 8.13 \\
\hline
\end{tabular}

${ }^{2}$ Means for root weight and GLY concentration within a harvest date were not significantly affected by dodder infection $(\mathrm{P}>0.05)$.

${ }^{y}$ Concentration calculated on a weight-to-weight basis.

${ }^{14} \mathrm{C}$-labeled GLY as the treated leaf, as did the top third of the carrot root (Table 1). In plants not infected by dodder, a gradation in the amount of ${ }^{14} \mathrm{C}$-labeled GLY in the root was found (Table 1). The GLY concentration in the root of plants either infected or not infected by dodder was the same (20 ppm). The GLY concentration in the various tissues sampled followed the same pattern as that obtained for ${ }^{14} \mathrm{C}$-labeled GLY content (Table 2).

Day 45 after treatment. At 45 DAT, the treated leaves of plants infected with dodder or not infected contained more ${ }^{14} \mathrm{C}$ labeled GLY than any other tissue. In plants infected with dodder, the petiole of the treated leaf and the dodder tissue contained more ${ }^{14} \mathrm{C}$-labeled GLY than any other tissue sampled (Table 1). In plants not infected with dodder, the petiole of the treated leaf contained more ${ }^{14} \mathrm{C}$-labeled GLY than any of the other tissues sampled (Table 1). In both dodder-infected and noninfected plants, all the other physiological sinks tested contained the same levels of ${ }^{14} \mathrm{C}$-labeled GLY. As at the other harvest dates, the concentration of GLY in the whole roots was not significantly affected by the dodder status of the plants $(\approx 2$ $\mathrm{ppm}$ ). Also, as at the other harvest times, the GLY concentration in the various tissues sampled followed the same pattern as that obtained for ${ }^{14} \mathrm{C}$-labeled GLY content (Table 2).

The concentration of GLY in the entire roots gradually increased from 1 to 14 DAT, and then diminished from 14 to 45 DAT. Similar trends were seen in the treated leaves, the petioles of the treated leaves, and the crowns (Table 2). The plants at 45 DAT not only had larger roots than those at 14 DAT (Table 3 ), thus diluting the GLY concentration, but also had more leaves that were formed after GLY application (Table 4). The leaves formed after GLY application also acted as physiological sinks early in their development. Since the carrot root acts as an energy source for newly forming leaves, photoassimilates move from the root to these leaves. As GLY also moves in the stream of photoassimilates; some of the GLY initially translocated from the treated leaf to the root probably was eventually translocated to those leaves formed after GLY application.

The weight of roots of plants infected by dodder did not increase significantly from 1 to 14 DAT, but that of noninfected plants did (Table 3). Weight of the whole roots increased from 14 to 45 DAT in both types of plants.

Absorption of ${ }^{14} C$-labeled GLY directly by dodder. Dodder grows on top of the host plant foliage and, in severe infestations, completely covers host foliage. Such a condition may present a physical barrier to GLY reaching the host plant and may have produced the effect seen in field experiments, where dodder infestation apparently protected carrot plants from the phytotoxic effects of GLY (Bewick et al., 1988a).

One DAT of dodder stems directly with ${ }^{14} \mathrm{C}$-labeled GLY, dodder tissue contained an average of $33.2 \mathrm{dpm} / \mathrm{mg}$ of dry weight. This amount was eight times the level found in dodder tissue 1 DAT when dodder-infected carrot foliage was treated with ${ }^{14} \mathrm{C}$ labeled GLY (Table 1). Less than 1\% of the GLY applied directly to the dodder stems had been absorbed by the dodder tissue, however, while the carrot plant had adsorbed $14 \%$ of the applied GLY. Dodder is covered with a thick waxy cuticle that probably was responsible for the low level of absorption directly by the dodder stems. In addition, the concentration of GLY in the solution applied directly to dodder stems was far less than that used on carrot foliage in these experiments. Buhler and Burnside (1983) found that GLY toxicity increased as carrier volume decreased, indicating increased GLY absorption with higher GLY concentration. The relatively high amount of ${ }^{14} \mathrm{C}$ labeled GLY in the dodder indicates that direct absorption may have caused phytotoxicity to dodder in field experiments. Therefore, the dodder canopy in field experiments may have presented a physical barrier to GLY reaching the carrot foliage, thus preventing injury to the crop. This factor may be more important than the protective effects of the physiological sink created in the host by the dodder.

The U.S. Environmental Protection Agency has established a tolerance for GLY concentration in the edible portion of root vegetables of $0.2 \mathrm{ppm}$ (U.S. Government Printing Office, 1989).

Table 4. Dry weight of carrot tissue at various times after treatment with ${ }^{14} \mathrm{C}$-labeled GLY.

\begin{tabular}{|c|c|c|c|c|c|c|c|c|}
\hline \multirow[b]{3}{*}{ Physiological sink } & \multicolumn{4}{|c|}{ Infected } & \multicolumn{4}{|c|}{ Not infected } \\
\hline & \multicolumn{8}{|c|}{ DAT } \\
\hline & 1 & 7 & 14 & 45 & 1 & 7 & 14 & 45 \\
\hline & \multicolumn{8}{|c|}{$m g$} \\
\hline Treated leaf & $751 \mathrm{~B}$ & $525 \mathrm{~B}$ & $608 \mathrm{~B}$ & $433 \mathrm{~B}$ & $1,680 \mathrm{~A}$ & $1,400 \mathrm{~A}$ & $623 \mathrm{~B}$ & $640 \mathrm{~B}$ \\
\hline Petiole of treated leaf & $128 \mathrm{C}$ & $116 \mathrm{C}$ & $255 \mathrm{BC}$ & $253 \mathrm{BC}$ & $423 \mathrm{~B}$ & $336 \mathrm{~B}$ & $597 \mathrm{~A}$ & $395 \mathrm{~B}$ \\
\hline Crown & $335 \mathrm{~A}$ & $425 \mathrm{~A}$ & $557 \mathrm{~A}$ & $1,510 \mathrm{~A}$ & $411 \mathrm{~A}$ & $3,450 \mathrm{~A}$ & $527 \mathrm{~A}$ & $1,491 \mathrm{~A}$ \\
\hline \multicolumn{9}{|l|}{ Root } \\
\hline Top third & $2,970 \mathrm{~B}$ & $2,700 \mathrm{~B}$ & $5,230 \mathrm{~B}$ & $9,980 \mathrm{~A}$ & $2,570 \mathrm{~B}$ & $2,570 \mathrm{~B}$ & $3,860 \mathrm{~B}$ & $11,300 \mathrm{~A}$ \\
\hline Middle third & $1,540 \mathrm{BC}$ & $1,700 \mathrm{BC}$ & $3,130 \mathrm{~B}$ & $4,890 \mathrm{~A}$ & $1,380 \mathrm{C}$ & $1,910 \mathrm{BC}$ & $2,500 \mathrm{BC}$ & $5,310 \mathrm{~A}$ \\
\hline Bottom third & $573 \mathrm{CD}$ & $626 \mathrm{CD}$ & $1,380 \mathrm{BC}$ & $2,280 \mathrm{~A}$ & $465 \mathrm{D}$ & $620 \mathrm{CD}$ & $1,730 \mathrm{AB}$ & $2,180 \mathrm{AB}$ \\
\hline \multirow{3}{*}{$\begin{array}{l}\text { Youngest leaf at time of } \\
\text { GLY application } \\
\text { New leaves formed after } \\
\text { GLY application }\end{array}$} & & & & & & & & \\
\hline & 395 & 708 & 1,092 & --- & 395 & 960 & 865 & 2,138 \\
\hline & $\cdots$ & 203 & 674 & 7,459 & $\cdots$ & 429 & 474 & 6,944 \\
\hline
\end{tabular}

${ }^{2}$ Mean separation in rows by LSD at $P=0.05$. 
The concentration of GLY in the roots of the carrots in this experiment exceeded that tolerance level. This means that under the conditions used in this experiment, GLY would not be an acceptable treatment for dodder control in carrot. Several aspects of the experimental procedure must be considered before a final judgment as to the safety of this treatment can be made. Since the carrots were grown in controlled environments and no water was allowed to contact the foliage of the plants, none of the GLY applied was rinsed from the foliage. This is a situaiton that probably would not occur under field conditions, except, possibly, in arid areas where furrow irrigation is used, and may have led to more total GLY absorption than would be found in the field. Second, all the GLY that would normally be applied to an entire plant in the field was applied to a single leaf in these experiments, a procedure that may have caused some abnormalities in the translocation patterns.

The decrease in concentration of ${ }^{14} \mathrm{C}$-labeled GLY in the carrot root from early in the growing cycle (14 DAT) to a time corresponding to commercial harvest (45 DAT) indicates that it may be possible to lower GLY concentration in the roots of carrot by lengthening the interval of time between GLY application and carrot hamest. This procedure may make the use of GLY as a broadcast application practical for control of dodder.

\section{Literature Cited}

Baird, D. D., R.P. Upchurch, W.B. Homesley, and J.E. Franz. 1971. Introduction of a new broad spectrum postemergence herbicide class with utility for herbaceous perennial weed control. Proc. North Central Weed Control Conf. 26:64-68.

Bewick, T. A., L.K. Binning, and M.N. Dana. 1988a. Postattachment control of swamp dodder (Cuscuta gronovii) in cranberry (Vaccinium macrocarpon) and carrot (Daucus carota). Weed Technol. 2:166-169.

Bewick, T. A., L.K. Binning, and N.E. Balke. 1988b. Absorption and translocation of glyphosate in cranberry. HortScience 23:90. (Abstr.)

Buhler, D.D. and O.C. Bumside. 1983. Effect of spray components on glyphosate toxicity to annual grasses. Weed Sci. 31:124-130.
Coupland, D. and D.V. Peabody. 1981. Absorption, translocation, and exudation of glyphosate, fosamine, and amitrole, in field horsetail (Equisetum arvense). Weed Sci. 29:556-560.

Davis, H. E., R.S. Fawcett, and R.G. Harvey. 1979. Effects of frost and maturity on glyphosate phytotoxicity, uptake, and translocation. Weed Sci. 27:110-114.

Dawson, J. H., F.M. Ashton, W.V. Welker, J.R. Frank, and G.A. Buchanan. 1984. Dodder and its control. U.S. Dept. Agr. Farmers' Bul. 2276.

Dawson, J.H. and A.R. Saghir. 1983. Herbicides applied to dodder (Cuscuta spp. ) after attachment to alfalfa (Medicago sativa). Weed Sci. 31:465-471.

Devine, M. D., H.D. Bestman, C. Hall, and W.H. VandenBorn. 1984. Leaf wash techniques for estimation of foliar absorption of herbicides. Weed Sci. 32:418-425.

Fer, A. 1981. Recherches sur les voies de transport impliquées clans l'alimentation d'une phanérogame parasite. Etude sur des feuilles isolées parasites par Cuscuta. Physiol. Vég. 19:177-196.

Hoagland, D.R. and D.I. Arnon. 1950. The water-culture method for growing plants without soil. California Agr. Expt. Sta. Circ. 337.

Kuijt, J. 1977. Haustoria of phanerogamic parasites. Annu. Rev. Phytopathol. 17:91-118.

McAllister, R.S. and L.C. Haderlie. 1985. Translocation of ${ }^{14} \mathrm{C}-\mathrm{gly}-$ phosate and ${ }^{14} \mathrm{CO}_{2}$-labeled photoassimilates in Canada thistle (Cirsium arvense). Weed Sci. 33:153-159.

Putnam, A.R. 1976. Fate of glyphosate in deciduous fruit trees. Weed Sci. 24:425430.

Snedecor, G.W. and W.G. Cochran. 1982. Statistical methods. 7th cd., 2nd printing. The Iowa State Univ. Press, Ames. p. 372.

U.S. Government Printing Office. 1989. Code of federal regulations. 40 CFR 180.364, glyphosate tolerance. Office of Federal Register, National Archives, Washington, D.C.

Waldecker, M.A. and D.L. Wyse. 1985. Chemical and physical effects of accumulation of glyphosate in common milkweed (Asclepias syriaca) root buds. Weed Sci. 33:605-611.

Wolswinkel, P. 1977. Physiological aspects of a parasitic relationship. The effects of Cuscuta on its host. PhD Diss., Univ. of Utrecht, Netherlands. 